Journal of Social Sciences 8 (1): 1-12, 2012

ISSN 1549-3652

(C) 2012 Science Publications

\title{
Nice CV! You Will Hear From Us: Canadian Labor Market and the Phenomenology of the Marginalized Ethnic Professional Migrant
}

\author{
Buster C. Ogbuagu \\ College of Arts and Sciences \\ Department of Social Work, University of St. Francis, \\ 500 Wilcox Street Joliet, Illinois, 60435, USA
}

\begin{abstract}
Problem statement: In the last several decades, the quest for human capital has meant that Canada's consideration of potential migrants hinged largely on the needs of its labor market. Applying the human capital theory espoused by Schultz (1961) Canada, like other industrialized countries shows interests only in those migrants who it strongly believes will make exemplary contributions to the economy. Approach: Whereas migrants of European descent have run the gauntlet of Canadian labor market integration, Visible Minorities especially have experienced and share narratives of unprecedented devaluation of their education, training, skills and lived experience. At the premigration stage, most of these migrants were highly qualified professionals in various fields. At the post-migration phase they are cleaners, cab drivers, nurse's aide, telemarketers and despondent citizens. Results: This study evaluated international lived experiences of some ethnic migrant professionals to Canada; provided a comparative analysis of the migrant professionals and resident or non-migrant types. It examined systemic barriers to full integration, including the intersectionality of race, ethnicity and gender in the integration or exclusion of migrants from the labor market and participation in the economy. Conclusion: It proffered research-based policy approaches to full integration of migrants into the labor market, economy and citizenship participation.
\end{abstract}

Key words: Immigration, ethnic/visible minority, race, gender, employment, exclusion, integration

\section{INTRODUCTION}

With the globalization of enterprise, such industrialized economies as Canada have increasingly and diligently sought out and admitted a large number of points-tested professionals and skilled migrant workers from across the globe. To this extent, 59.6 percent of new immigrants to Canada in 2004 have arrived with the status of economic migrants (NSO, 1995). Canada's visible minority population includes the following groups: Chinese, South [Asian East Indian, Pakistani, Sri Lankan]; Black-including Africans, Filipino, Latin American; Southeast Asian [Cambodian, Indonesian, Laotian, Vietnamese]; Arab, West Asian [Afghan, Iranian]; Japanese, Korean and Pacific Islander (NSO, 1995). Inasmuch as Canada has delighted from the "importation" of this human capital, its purveyors on landing have remained on the margins of socioeconomic integration.

(Li, 2001; Krahn et al., 2000) all speak to the Canadian government's decades-long practice of applying the human capital theory (Schultz, 1961) to enlist the immigration of a large pool of highly skilled immigrants to Canada. With the opening up of immigrations in recent years to previously undesirables, (Frost, 2005) most of these "imports" are increasingly ethnic minorities, who ostensibly are for the purposes of promoting growth and competitiveness of the Canadian economic system. MacBride-King and Benimadhu (2004) estimate that about 73 percent of internationally educated professionals in Canada, are ethnic or visible minorities, a lot of whom face labor market exclusion. Highlighted the interview by the New York Times with Joe Volpe, Canadian Minister of Citizenship and Immigration. The minister confirmed the existence of an esoteric network of professional bodies and licensing organizations, whose activities figuratively hold the integration into the labor market of highly qualified and skilled immigrants at a full nelson.

Girard and Bauder (2005) argue that most immigrant professionals upon landing in Canada immediately find that gaining admission into the corresponding professional field was contingent on legal eligibility for employment in professions that are highly regulated. Worse still, they realize that their credentials, skills, training and employment experience must be evaluated by licensing professional bodies, which always, as if by default, deem the international 
credentials and work experience of immigrant professionals inadequate, unacceptable, or even inferior to those of their Canadian counterparts (Goldberg, 2000). These outcomes force highly educated, highly skilled, professional migrants into low-wage, careerdevoid and McJob occupations).

Goldberg (1993) insists that at all levels of government rhetoric are embedded notions of tolerance, equity and diversity, while on the other hand harboring serious ambivalence in setting up institutions and modus to arrive at an egalitarian society. Maintains Goldberg, "the major paradox of modern liberal societies like Canada was that in its quest to bring about racial equity it employs misguided parameters, notions and definitions of culture, race and racism" (p: 349). The flawed designs then permit the various facets of inequities to thrive, become internalized, reproduced and sacrosanctified.

In the case of the English/French duality as equal founders of Canada, Goldberg opines that an inclusionbased ethos is perceived by them as "hara-kiri," [emphasis added] therefore inimical to their construction of the Canadian identity. Not minding the English/French dichotomy, they appear to agree on the perpetuation against minorities of inequalities in job, social and economic opportunities The Canadian Multiculturalism Act, 1990 (Lopes and Thomas, 2006; Cameron, 2004; Wherrett, 1997) Contingently, most inclusion-based outcomes appear as farces at best. I will deal with these issues in more details later in the study.

The study applies relevant literature reviews and phenomenological interviews in its attempt to understand the issues implicated in the fringing of highly educated, highly skilled and highly experienced ethnic professional migrants. Ostensibly, these were primarily admitted to Canada on the basis of their human capital and potential for enhancing the economic growth of Canada. It first explores the ethnic origins of the professional immigrants, with a view to comprehending the value and worth placed on their professional qualification by the professional and licensing bodies in Canada. Secondly, it explores some of those issues that may rightly be implicated in the fringe status of highly skilled foreign professionals. Thirdly, it evaluates the outcomes of the human capital waste within the Canadian economic system and its implications for the continued application of the human capital theory by the Canadian government in determining eligibility for landing and integration into its labor market. Finally, the study pursues possible solutions to the despondent outcomes of the human capital expropriation and waste, with a view to enhancing Canada's economic growth on one hand and on the other, the inclusion of ethnic minority skilled professionals in its citizenship, social and body politic.
Review of the relevant literature: By default, new immigrants must run gauntlets as rites of passages, which would become the vehicle for their full integration into the society, particularly the labor market. In the case of Canada, most immigrants enter, based on a points-tested system that highlights their level of education and skills as a prerequisite for admission into Canada, as well as ability to rapidly reenter the labor market. Reitz (2001) argues that in the 1960s, when Canadian immigration began to accept minorities from across the globe on the basis of education and human capital, integration of these professional migrants were relatively easy, despite the devaluation of their qualifications by Canadian employers. (Murray et al., 2000; Grant, 1999; Reitz, 2001) believe that this situation has regressed significantly in recent decades, although the Canadian government continues to insist and has even upped the ante in its application of the human capital theory as the major selection criterion.

Reitz (2001) is uncertain why new immigrant professionals to Canada are fringed in recent decades, contrary to the $1960 \mathrm{~s}$. One thing is clear and that is the fact that the use of human capital and skill for selecting new migrant professionals to Canada makes nonsense of the program if the immigrants on landing are only able to obtain employment that is well beneath their qualifications, training and skills. It is paradoxical that the Canadian government has previously engaged in policy initiatives research on the plight of professional migrants, with significant findings. However, it appears to have been lukewarm in addressing aberrant issues emanating from this program (Watt and Bloom, 2001; Stasiulis, 1990; Abella, 1984). One of such initiatives was the Employment Equity Act of 1986.

The employment equity act: The Employment Equity Act of 1986 first began with and applied to Federal government and Crown Corporations, as well as federally regulated employers, in supervision of a hundred or more employees. Obviously, the EEA was aimed to level the playing field, as well as remedy the exclusionary practices against designated groups as located in visible minorities, Aboriginal Peoples, persons with disabilities and women. The Act was designed to provide a fulcrum for inclusion, by isolating those practices and policies that are prima facie neutral, but with demonstrable systemic outcomes in racism and exclusion of minorities (Henry et al., 1998; Henry, 2006). Checks and balances were created through the submission of an annual report to the Canadian Employment and Immigration Commission by all employers regulated by the federal government. 
Samuel and Karim (1996) assert that the EEA has worked more on paper as shown by a limited shift in the status quo. They cite the fact that Canada's public service for instance indicated only 2.7 percent Visible Minorities' representation in 1987, while this category makes up 6.3 percent of the general population. By March 1996, it rose slightly by 4.5 percent, which is a regression, in consideration that the Visible Minority population had doubled to 13 percent. At the managerial level of the public service and as buttressed by Reitz (2001) Visible Minorities' presence was only 2.3 percent representation. In succinct terms, the higher the managerial level, the lighter in complexion its occupants become. Samuel and Karim (1996) maintain that the paradox and farce of the Employment Equity Act resided in the fact that whereas the population rate of Visible Minorities was experiencing an exponential growth, the employment rate was actually falling or at best, static. Poignantly, the EEA forgot the private sector.

Ethnic and visible minority status: Mainly on account of their "entrance status" and assigned low social standing, Li (1988); Walker (1980) state that ethnic minorities across Canadian institutions experience a lot of discrimination and exploitation in employment, as well as in education, housing and social services (Samuel and Karam, 2000; O'Connor, 1999). This minority condition was the prompt for the Federal government to enact the Employment Equity Act, even after it had been historically an active participant in the marginalization of ethnic minorities (Foster, 2005). In Institutional discrimination, employment practices that have prima facie neutrality have ingrained dire and farreaching consequences on minorities and other disadvantaged groups (Henry, 2006). Argues that there is a routinization of minority exclusion from the labor market and handsomely-rewarding corporate positions, contingent on another type of exclusion from the networks of contacts. This has a propensity to preclude such minorities from having access to information on available job pool. Breton indicts systemic and institutional racial discrimination in the labor force, which he argues inordinately and more than any other type of intolerant attitude impacts on visible minorities.

If structural and linguistic differences exist between employer and potential employee, the latter's ethnic origin may be a liability compared to a competitor who shares the employer's cultural background (p.37).

(Abella, 1985; Henry and Ginzberg, 1985; Billingsley et al., 1985; Ontario Human Rights Commission, 1983) conducted studies that document the systemic and individual discriminatory practices preferred against minorities in Canada, in interviews and recruitment. Similar findings on minority under and unemployment, lower wages and dead-end jobs have been unearthed by (Myers, 2005; Gupta, 1996; Halli et al., 1991; Kluegel, 1990; Li 1988; Kluegel and Smith 1982; 1986). All the authors agree that systemic exclusion, leading to lack of jobs or low-paying, deadend jobs for minorities is proportional to the nullification of strategies for survival for their nuclear, extended families and communities. For Reitz (2001) the powerlessness of minorities on the labor force, in turn maximizes the appropriation of surplus capital and its accumulation by the majority group.

Theoretical perspectives according to Mensah (2002) which underscore the institutionalization and reproduction of racism, as well as the subordination of minorities, including Blacks in the Canadian labor market, include-the human capital theory, the Marxist theory, labor market segmentation theories and the vertical mosaic thesis. The scope of this study limits their discussion. Mensah surmises that whereas jobs with specialization, higher wages, mobility, greater unionization, generous pensions and other perks constitute the primary tier, the secondary tier, where most ethnic minority professional migrants are deliberately located is saturated with low-paying, deadend jobs that have neither mobility nor career path. Torczyner and Sharon (2001) put it succinctly when they implied that even the attainment of higher educational and occupational status, by minorities under the secondary labor system, do not necessarily and automatically translate into upward social mobility or greater economic outcomes. It is possible that the data for Quebec, with a government-led, constitutionally sanctioned monolingualism and overt nationalist fervor would be anything but low.

Methodology: This study is informed by ethnographic research, which applies qualitative research and interpretive method-beginning with observation and or intuition. According to Harlos et al. (2003) ethnography provides the fulcrum for defending outcomes, as well as for further or enhanced ability to examine processes. Preference of qualitative research applied here is its capacity to permit the search for data capable of supporting, contradicting or pointing to other research directions. Additionally, the use of qualitative ethnography is that it is predicated on interviews, observations and focus groups. It also allows the researcher to gain insight into organizational structures and settings, social processes and more poignantly, lived experiences (Strauss and Corbin, 1990).

The essence of this methodology according to Strauss and Corbin is its holistic properties in evaluating research, as well as its ability to fend off standardized categories that have been predetermined. 
This is accomplished through the collection of information that is based on written and spoken text, while simultaneously promoting grounded data. Indeed, Ulmer and Wilson (2003); Hines (2000); Miles and Huberman (1994) argue for the preference of qualitative over quantitative research in that the former permits the researcher to document phenomena, such as emotions, social relationships, cultural and social organizations as the participants perceive them (Davies, 1999). On the other hand, the authors argue on the impossibility of the quantification of social processes, relationships and lived experience to the same degree. Unlike quantitative research, qualitative research which I have utilized in the study avoids generalizations, while it engages in depth and processes for uncovering and interpreting the meanings and reasons behind the experiences of study participants (Skinner et al., 2000; Maxwell, 1992).

Qualitative research has an inductive property, which allows for the collection of data to build concepts, hypotheses, or theories derived from observations and intuitive understandings. Additionally, because qualitative research designs can be altered to fall in tandem with the dynamic yearnings of the phenomenon, they are therefore both flexible and amenable.

Constellation of research participants: 32 professional men and women in Montreal and Ottawa, participated in the study. They comprised 13 professional women and 19 men, previously from several geographical locations of the world where Canada frequently recruits its professional migrants. They were from, Asia, the Middle East and Africa. 8 of the participants had earned terminal degrees ( $\mathrm{Ph}$. D), including two with an MD; 15 had a Master's degree and 9 had Bachelor's degrees. Among the participants were geologists, mining, geological and petroleum engineers, architects, family physicians, pharmacologist and other health and allied professionals. All had immigrated to Canada within the last 3-10 years contingent on a pointsbased system. The participants were randomly selected based mainly on their expressed interest and availability to be part of the study.

Research questions: The following questions were applied in the study:

- What in the recent decades is/are the push and pull factors behind an increase in ethnic professional migration to Canada

- What were the pre-migration professions, occupations and employment experiences of ethnic migrants in their native countries
- What are the post-migration employment and occupational experiences of ethnic migrant professionals in Canada

Data collection process: Contacts and solicitations for participation were made through telephone calls, emails, home visits and introductions by other participants resulting in one-on-one interviews. The interviews were tape-recorded for durations of 1.5 to 2 hours at various locations that were nominated by each participant. The one-on-one interviews were complimented by 3 focus groups, two comprising 10 interview participants each, while the last group was made up of 12 participants. The focus group process was also tape-recorded. The use of focus groups was to evaluate and make comparisons with the responses obtained from the one-on-one interviews that had earlier been conducted. During the solicitation phase and consistent with the ethical considerations for research involving humans, all participants received written Informed Consents, were provided ample time to articulate the documents and subsequently agreed to participate of their own volition. The data so collected from the one-on-one interviews and the focus groups provided analytical fulcra for highlighting and pairing emanant common themes.

Limitations of the study: One of the limitations of this research is that the researcher self identifies as an ethnic minority. In addition to this identity, the researcher, during his early years as a resident of Quebec and Ontario, Canada experienced some of the same subjectivities-unemployment, discounting of educational attainment, qualifications, knowledge and transferable skills as the research participants in the study. Although this lived experience can be deemed helpful in the research and other narratives, it is highly feasible that it may contain certain unpremeditated biases that influenced, ultimately informed the interview style, as well as yielded certain outcomes in the study. The study did not contain a control group, which would highlight if and how some other ethnic migrant professionals successfully found and currently retain employment in their professions. Additionally, my use of ethnographic and phenomenological interviews, which by default entailed close interactions with the participants, may have overtime created situations that humanized them, consequently, have potentials for generating unintended sympathies and biases in the study.

\section{Findings and analysis:}

Emerging significant themes: There were significant themes that emerged from the interviews and focus 
groups, which were applied in analyzing and comprehending the conditions of ethnic migrant professionals in Canada. These include educational attainment of the migrants; opportunity cost of migration; high education penalty; immigrant skill underutilization and earning outcomes; gender; ethnicity and race.

\section{Discussion of themes:}

Educational attainment of ethnic minority immigrant professionals in Canada: As indicated by the respondents' high educational profile, most ethnic minority immigrants on landing in Canada under the human capital paradigm are highly educated, well trained and skilled at their professions. The respondents who have been in Canada for 3-10 years provided narratives of their exclusion from the Canadian labor market, despite having equivalent or superior educational attainment than the Canadian-born population. One of the respondents from Nigeria obtained his Ph.D. in mining engineering from a Canadian university. He spoke about how he was hired by a mining industry and promised promotion when he concluded his degree. He was required to take a White, junior colleague under his wings for training purposes. When he concluded his studies, he was passed up for promotion and instead the junior staff he was training was given the position, forcing him to resign. He is still searching for an appropriate job as I compile this report.

... when I came to Canada, I was doing my $\mathrm{PhD}$ and got, I got employed by a company, even before I finished my $\mathrm{Ph} . \mathrm{D}$, in a position that, you know, commanded a lot of responsibility. And em, I delivered, I worked for the company for seven years. And I left the company in a very, very sad circumstance, because I was promised that when I finished my $\mathrm{PhD}$, I will be elevated to the rank that I was working on, but not recognized. And when I got my $\mathrm{PhD}$ and a very, very nasty experience... Yeah, yeah and I left the company. I was more or less forced out of the company. So, it was very nasty, the...details are really bad and em and em...

This finding is in consonance with the educational qualifications of foreign professionals based on a 2001 survey by SC (2003) which puts the percentage of those who hold at least one foreign credential at 76 percent. This survey found that racialized group members were overrepresented among highly educated categoriesBachelor's, Master's and Doctorate degrees. Conversely, they were underrepresented under the trades and colleges graduates ranks, as well as underrepresented among those with less than a grade 12-13 education.

The high opportunity cost of migration: New minority professional migrants to Canada endure significant transition penalty for reasons that are far from their educational qualifications, knowledge, skills and language. The respondents in this study expressed that they appear to be receiving an inordinate penalty for moving to Canada vis a vis their non-racialized counterparts (Hum and Simpson, 2002). All spoke about how the Canadian immigration officials who came to their countries of birth or residence spoke strongly about coming to Canada.

I had a friend who had a hint of a particular fair, it's like a Trade Fair and Expo... Not Job fair, call it Immigration Fair...where various countries like New Zealand, South Africa, Canada and Australia... they were at this Fair trying to woo immigrants from [location expunged] to come to their country...Basically, I think they were looking for professional...skilled workers... different provinces were represented; Quebec Manitoba was there; I think Ontario and Alberta. So they had their different boots and then Immigration Canada itself. So, it was like they were kind of wooing us, telling us the good things about Canada and at the same time telling you, well, like you know, come over, Canada is good and then you wouldn't believe it, they even, they even brought eh, grocery fliers to show us kind of the cost of living that is low in Canada.

The respondents all expressed how their high hopes were dashed as soon as they landed in Canada, sought jobs in their fields, only to have their foreign credentials, skills and work experience devalued and relegated into obsolescence. Whereas some were stoical, many declared their exasperation at the interminable situation and voiced increasing temptations to return to their countries of origin. One of the participants who trained as a foreign pharmacologist and toxicologist stated:

And even when I had acknowledgement or had time to speak with someone with any of these eh employers, the problem of Canadian experience was a big deal. And I said, if you talk of Canadian experience where am I gonna get it? And honestly, I had decided that its either I do a professional job or no job at all. But then, I had a family of three and within this period my wife gave birth to a second child. So things were getting tough. I came in with some amount of money but then I had to settle, I had to rent an apartment, I had to start life anew, buying from cutlery to everything, to bed. So the amount of money that I came down to Canada was depreciating, was going down. Honestly, I must tell you, it got to the last hundred pounds, before I decided to, you know, swallow my pride and just go and do anything and I think the first job that I did was eh as a Telemarketer

Contingent on the 2001 Canadian Census, Statistics Canada (2001) expressed concern that recent immigrants 
who had been in Canada 1-5 years maintain at 12.7 percent an unemployment rate significantly higher than that of the Canadian-born population at 7.4 percent. For the lucky one/s (includes education and retraining) it now takes more than 10 years of "running the gauntlet" (emphasis added) in Canada for the unemployment rate of the migrant to attain the same rate as those found among the Canadian-born population.

The prompt for this study and title are largely informed by my experience as an educated, new immigrant from Nigeria and the unending job search frustration on landing in Canada. When my family was at the verge of starvation, I was forced to enter janitorial services as a cleaner. I recall attending all sorts of job-search clubs, associations and use of headhunters. I was told that a good Resume/CV was the bedrock of a successful search. I wrote the best possible curriculum vitae and tailored applications for each employer with limited outcomes. Some potential employers, who read my curriculum vitae in my presence or after I had submitted it called me to announce this refrain which still drums in my subconscious "Nice CV' You will hear from us." I am still waiting to hear from them close to 20 years after the fact. It is certain that I still would have been cleaning offices and lavatories had I not chosen to return to school.

On the nearly insurmountable job hunt experience by ethnic immigrant professionals, one of the participants shared this narrative:

I was with one high commissioner one day and he was trying to not ridicule but, but give a true assessment of the health care delivery in Canada... And he made another joke that in Canada, if somebody is going, suffering from a heart attack your best bet is to stop a taxi driver, that there is more likelihood that that taxi driver is a foreign trained physician, who might be able to help you medically, than waiting for an ambulance or going to the emergency room.

Higher education penalty [higher education at your peril]: 78.1 percent or 25 of the 32 respondents in this study indicated that they had been searching for jobs that meet their education, qualifications and training for the past 3-7 years, having mostly been employed in transient, career-devoid occupations, with little to no relevance to their education, skills and training. One of the respondents holds a Ph.D. in architecture.

...Since coming to Canada nearly four years ago I have applied to all sorts of building design and construction companies for job. I moved from Montreal to Ottawa, hoping to get a federal job. Worse' [exclaiming] No one wants to employ me. Some of the excuses is that I need license, others French and the bilingual thing. I agreed to do...but it is very expensive to take all the exams and feed my family at the same time. Another place I applied, they said I was over qualified. What can I do?

As the level of education rises, there is a concomitant increase in the relative difference between the unemployment rates of immigrants and the Canadian-born. Reitz (2001) argues that the unemployment rates of recent immigrants with a bachelor's degree are three times higher at 11.8 percent compared with 3.9 percent for Canadian-born degree holders. Statistics Canada (2001) buttresses this argument by adding that those professional and highly educated and skilled migrants having Master's degrees or earned doctorates endure unemployment rates that are more than 3.5 times those of Canadianborn with graduate level degrees. Another respondent had this to say:

...But then, honestly, I must say that if not that I knew I had a focus, I could have given up the patience and everything, because within the period while I was applying for jobs, I don't know if I wanna use the word arrogance. The arrogance of the corporate entities in Canada not to recognize anybody from outside the Canadian educational or whatever institutional system, it was very awkward and very poor. Because, if I juxtapose that with the way we were being wooed, you would think that it was just a fraud. Because we were kind of promised that oh, 'the highest it will take you is two months you will get a job, oh with your qualification, with your, with your line of study, oh you, they will be looking for you.

It appears bizarre that despite the high demand for post-secondary credentials and skills, recent immigrants with university education have been placed at roughly the same rate of unemployment as those who did not complete high school-"flunkouts" (emphasis added) (Reitz, 2001). The summation, according to Hum and Simpson (1999); Sawan, (1991) appears to be that Canadian employers treat schooling in certain countries of origin, mostly in Asia, Africa, the Caribbean and Latin America, differently from the way they treat schooling in Canada and other countries of origin, mostly European.

Human capital: Immigrant skills underutilization and earnings outcomes: 27 of the 32 or 84.3 percent of the respondents stated being underemployed and underpaid, a parlance that translates their current employment into areas beneath their education, training and skills and what Bauder (2003) describes as "brain abuse."

If anyone told me that I would be a cab driver in Canada I would have felt insulted but this is what I 
have been doing now for five years. I went to a good university I am a geological engineer...I know my job well, but I can't find a job in that field in Canada. Everyday, I apply for job, em...they say I need Canadian experience and I don't know exactly what is Canadian experience...okay, how can I get Canadian experience if no one wants to hire me first? Canadian experience comes with a job...

Generally speaking, highly educated, highly skilled immigrant professionals receive significantly lower emolument for their education than native-born Canadians (Hum and Simpson, 1999; Pendakur and Pendakur, 1998; Abbott and Beach, 1993). Buttress this argument by their findings that whereas in their home country 88 percent of highly educated ethnic minorities were employed in their professions, only 18 percent were employed and worked as professionals once they land in Canada. Reitz (2001) points out that in 1996 dollars, the total annual of immigrant earnings deficit from all three sources was $\$ 15.0$ billion, of which $\$ 2.4$ billion was related to skill under-utilization and $\$ 12.6$ billion was related to pay inequity. The identified earnings deficits of immigrants may emanate from subjectively assessed lower immigrant skill quality, under-utilization of immigrant skills and pay inequities for immigrants doing the same work as native-born Canadians.

Gendered Immigrant employment and earned wages in relation to qualification: All the professional immigrant women in this study and there were 13 of them, attested to receiving earnings that were not just below their education and training, but also below those of the other male respondents, even when controlling for similarity, specificity in job, education and skills training. One of the female participants narrated her story.

I am trained as a psychologist and have been in public and private practice...family therapy before coming to Canada. I just wanted a better life for my children, that's why am here in Canada, I am working at a Day-care center minding the children and the pay is terrible. But you see, they use my training in psychology, but don't pay me a psychologist salary. One man was employed after me in the same position, but he also gets paid, higher than me. In fact, because I am [ethnicity expunged] and a lot of them, you know, are in Canada as domestic servants, some of the parents want me to work for them...some even want to take advantage of me...they think I don't have papers [legal residency].

Here again we observe gender discourses at play that continue to hold minority immigrant professional women to ransom. Although all immigrant professionals receive lower wages than native-born Canadians, this disparity is amplified by gender, furthering the oppression of women (TBCS, 2000).
Among women (Reitz, 2001) the earnings of the nativeborn rose $\$ 1815$ in light of each additional year of education. This represents, in dollar amount lower wage and emolument gap than for native-born men but represents an excess of 8 percent of the average earnings of native-born women. The education premium for native-born women translates to about twice what it is for immigrant women at $\$ 956$. At $\$ 6,000-\$ 7,000$, the premium for a university degree for native-born and immigrant women mirror each other.

What is the complicity of racism and racialization in Minority professionals' fringing? In the drive to be economically competitive, the Canadian government vigorously and purposefully attracts skilled immigrants from their home countries through an aggressive immigration policy. This policy, in principle that is, emphasized to the prospective immigrant the potential to improve their lives and be successful contributors to a modern economy and multicultural society. Unfortunately no one told them anything about dictions and accents.

...eh I speak English and French fluently and of course my native language in Africa, you know? I am now tired of applying for jobs after 4 years of trying. Of course, my names are French because of colonization...s so you will not know that I am not White Quebecois. So when they invite me for interview and I attend and they see oh' am Black... they are shocked and surprised and immediately they will tell me that the position has been filled...it's so unfair.

(NSO 1995; Li, 1988; 2001; Reitz 2001) Have observed that many of these ethnic professional migrants find themselves relegated to precarious employment in low wage, McJob sectors. Why? Human-made barriers in the Canadian economy vigorously deny them the opportunity to obtain employment and compensation commensurate with their education, training and experience. 23 of the 32 or 71.8 percent of the respondents were certain that they were denied employment due to their accent or the way they tried to communicate in English. Teelucksingh and Galabuzi (2005) argue that the historical "addiction" (emphasis added) to employment discrimination by the majority population define, overshadow and continue to emasculate the Canadian public policy, which placed a large employment premium on occupational skills and educational attainment. Supporting the assertions by Teelucksingh and Galabuzi (2005), one of the participants, who expressed awareness of discriminatory practices against ethnic migrant professionals stated:

...so, that shows you how bad it is and that is that there are so many foreign-trained professionals in Canada doing menial jobs and all because specifically 
with physicians, many of them cannot afford the cost of training as a Resident. The cost goes into hundreds of thousands of dollars every year. So, it's difficult. So, apart from protectionism, color barrier, I think it's then that apprehension or I don't know that xenophobia, that who is sure that this guy is gonna do well.

Teelucksingh and Galabuzi point to the complicity of such social indicators as higher rates of poverty, sectoral and occupational concentrations seen along racial lines and high rate of unemployment and underemployment amongst racialized individuals. They also indict the failure of the acquisition of comparable education by racialized individuals to translate into comparable occupational status, compensation and mobility. For them, these are the raison d'être to exhume the agenda of the hegemoniously ascribed racial supremacy of the majority population that still resides and is abysmally entrenched in the Canadian labor market psyche among others. Percy-Smith (2000) adds neighborhood, individual, spatial, group, in addition to economic, social and political dimensions as indicators of social exclusion.

Are Muslims the new blacks: There were 10 Muslim respondents in the study, who also have clearly discernible Muslim or Arabic names. They narrated their challenging experiences trying to find jobs, mainly on account of their names. Some of the respondents stated that since the events of 9/11 Muslims have become the "New Blacks" for the purposes of broad spectrum discrimination, but especially in employment. In his argument, a rather outspoken Muslim argues for Muslims from India, Pakistan and Egypt. He stated that these were already working in Saudi Arabia and other Gulf nations, but were as it were, "lured" to Canada under the independent professional category. Soharwardy opines that the recruiting Canadian officials neglected to advise the new immigrants about the actual situation in Canada, only to arrive and find themselves and families in straits. These professionals have been left between the rock and a hard place after having sold their homes, property and now exhausted their savings. They cannot return home due to the shame that a return would endow them, as well as the fact that there actually is nothing to return to, including the jobs that they had left behind in preference for migration to Canada. On the other hand, remaining in Canada with their depleted savings and lack of employment opportunities becomes an everyday struggle.

Khalema and Wannas (2003) argued that every Muslim in North America and Europe to a lesser extent is suspect. Just having a Muslim name or being dressed as one are enough grounds for discrimination, even harassment irrespective of actual religious belief. However and according him, even those Muslims who try to blend into the Canadian and western secularity have not been spared and are not immune from the discrimination. This argument supports employment narratives by some of the Muslim participants in this study. Of the 10 Muslim participants from the Middle East and Asia, 8 informed me that they were employed in jobs that made a mockery of their educational attainment, skills, pre-migration qualification and status. Two of the participants in this study attested to being medical doctors in their countries, with certificates to boot, but stated that they now drove taxi cabs, since they have been largely unable to work in their profession on migrating to Canada. Most of the affected new Muslim immigrants are professionals, engineers, geologists, computer programmers, medical doctors, bankers, accountants and business professionals. However, since their arrival in Canada, most of them can only find daily wage employment as security guards, cleaning workers, at McDonalds, at KFCs, at Burger Kings, taxi drivers, etc.

(Kincheloe, 2010; Graham, 1988; Khalema and Wannas 2003) attribute these exclusionary practices in work and other appurtenances of Canadian society to suspicions that are catalyzed not just from Islamophobia, but one that attained its crescendo from post 9/11.

Recommendations: The following represent recommendations and future policy directions for dealing with the issue of marginalized ethnic and indeed, other professional migrants to Canada.

Bridge, internships, mentoring and national standards initiatives: Bridge, Internships, Mentoring and National standards initiatives as suggested by Alboim (2003) offer important integrational tools especially for Visible Minority migrant professionals in the workplace. In the case of internships, bridges and mentoring, they represent sustainable ways of obtaining the so-called "Canadian experience" through "shadowing" of other already-working colleagues. They also represent ways of forging networks and access to the increasingly hidden, global job market, obtaining and enhancing language skills, including accent and diction and Canadian-specific professional skills. Integration of these three processes has potentials, when ethnicity, race and gender are controlled for, to enhance the opportunity to be hired after the bridge, internship or mentoring period. However, for these to materialize and remain sustainable in a society that has internalized and benefitted immensely from "otherness," certain criteria have to be met. Those listed above, as well as 
access to professions and trades, regulatory bodies standards and a blinded application of these standards to evaluate foreign, especially ethnic minority professionals and their credentials have to be standardized, uniformized, legislated and mandated by the governments at the federal, provincial and Territorial levels.

Accessible and enhanced pre-migration information: The participants in this study attested to Canadian officials painting very glowing pictures of Canada. Although there are several push factors, this pull factor clearly represents an unintended tactic that frequently cost the potential migrants their critical thinking abilities. Outcomes from this study suggest a desire for open, forthright, current and very accessible information on the realities of Canadian immigration, including culture and values, social integration, job/career prospects, professional regulatory practices and how to navigate them. This exposure, it is hoped would allow potential professional migrants to "think things over" and arrive at a sound and informed decision before the often irreversible embarkation.

Bi-lateral-employer and professional migrant initiatives: The current practice of placing the burden of finding work on the professional migrant, rather than through bi or even multilateral initiatives, involving employers of labor, professional licensing bodies and other labor-demanding institutions is obsolete. In its stead should be genuine initiatives that strive to impress upon these enablers and hirers of labor that the qualifications, skills and experiences that professional immigrants bring to Canada are comparable, competitive, valuable and sustainable, despite their ethnicity, race, gender and sometimes funny-sounding accents and word pronunciations. It must include the redesign by governments, immigrant services providers and professional regulators of sustainable programs that strive to expose and interpret to licensing bodies and employers of labor the essence of the utilitarianism of the excellent human capital that the immigrant population is bringing. Other suggestions for the amelioration of this impasse includes the engagement of public and private service agencies charged with evaluating foreign and immigrant qualifications, which they would in turn interpret for employers.

Universal enforcement of the employment equity act and incorporating anti-racism initiatives: Current labor and employment practices in Canada, including unfortunately at the federal government level strongly suggests that the letters of the EEA are either lackadaisically applied or not applied at all. No, it is not on account of its lacking in comprehensive content and specificity. There is a strong suggestion from the study participants that the failure to fully implement is due mainly to the racial, social and cultural homogeneity of the assigned and would be enforcers and their sustenance and reproduction thereof. They argued that most Canadian institutions are simply not diverse, lack inclusivity and refuse to by race, gender, age, sexual orientation and other social discourses. It is also about the enforcers' aversion to committing class suicide or "seppuku." Most of the literatures used in this study and elsewhere suggest that racism and age-old systemic racist discourses (Cornish et al., 2000) and practices in the Canadian labor market, including governmental institutions, present as the "primus inter pares" in the barrierization of ethnic professionals, irrespective of their education, training and skills. Deliberate human engineering that hopes to successfully combat and dismantle this anomaly suggests cultural competency that includes, the redistribution at all levels of power and its appurtenances, accountability, repercussions for recalcitrance and above all, a Canadian collective and sincere revisit of race and "otherness" as a systemicmacro-level, rather than individual or micro-level phenomenon.

\section{CONCLUSION}

A global market place, driven by economic competition and quest for sustainable development translates into competition for manpower by industrialized nations, of which Canada is a serious contender. Currently, it would appear that the lemming rush by the Canadian government to recruit the most qualified foreign professionals for its economy presents as a wasted enterprise, in that the skills of such immigrants are allowed to become decrepit and atrophic. Implicated in this waste are the licensing processes, which deliberately apply "cult" (emphasis added) methods to erect social, economic and cultural barriers to the integration of foreign professionals in the Canadian labor market (Cornish et al., 2000).

Additional to this are hidden racist discourses, systemic in nature, which continue to exist, define Canada and account for the discounting and dismissal of foreign credentials by those who control the major economic means of production. As poignant as it is paradoxical, the immigrants who make it to Canada do so following a thorough and deliberate scrutiny by qualified recruiting Canadian officials of the credentials, knowledge and skills that are possessed by the intending foreign professionals. The question that 
begs for an answer is, if Canadian employers of labor cannot trust the immigrants for the reasons that have been documented in this study and elsewhere, should they not be trusting of their own official representatives?

\section{REFERENCES}

Abbott, M.G. and C.M. Beach, 1993. Immigrant Earnings Differentials and Birth-Year Effects for Men in Canada: Post-War-1972. Can. J. Econ., 26: 505-524.

Abella, R.S., 1984. Equality in Employment. 1st Edn., GP, Ottawa, pp: 393.

Abella, R.S., 1985. Research studies of the Commission on Equality in Employment. 1st Edn., The Commission, Ottawa, pp: 683.

Alboim, N., 2003. Fulfilling the Promise: Integrating Immigrant Skills into the Canadian Economy. 1st Edn., Caledon Institute of Social Policy, Ottawa, ISBN: 1553820134, pp: 54.

Billingsley, B. and L. Muszynski, 1985. No Discrimination Here? Toronto Employer and the Multiracial Workforce. 1st Edn., Urban Alliance on Race Relations and Social Planning Council of Metropolitan Toronto, ISBN: 0919456421, pp: 121.

Bauder, H., 2003. Brain Abuse", or the Devaluation of Immigrant Labour in Canada. Antipode, 35: 699717. DOI: $10.1046 /$ j.1467-8330.2003.00346.x

Cameron, E., 2004. Multiculturalism and Immigration in Canada: An Introductory Reader. 1st Edn., Canadian Scholars' Press, Toronto, ISBN: 1551302497, pp: 426.

Cornish, M., E. McIntyre and A. Pask, 2000. Strategies for challenging discriminatory barriers to foreign credential recognition. Proceedings of the Originally Presented to the National Conference Shapping the Future : Qulaification Recognition in the 21st Century, Oct. 12-15, Canadian Labour and Employment Law Journal, Toronto, pp: 1-26.

Davies, C.A., 1999. Reflexive Ethnography: A Guide to Researching Selves and Others. 1st Edn., Routledge, London, ISBN: 0415151902, pp: 257.

Murray, S., D. Drew and J. Zhao, 2000. Brain drain and brain gain: The migration of knowledge workers from and to Canada. Educ. Q. Rev.

Foster, C., 2005. Where Race Does Not Matter: The New Spirit of Modernity. 1st Edn., Penguin Canada, Toronto, ISBN: 0143017691, pp: 211.

Frost, L., 2005. Never One Nation: Freaks, Savages and Whiteness in U.S. Popular Culture, 1850-1877. 1st Edn., U of Minnesota Press, Minneapolis, ISBN: 081664490X, pp: 241.
Girard, E. and H. Bauder, 2005. Barriers blocking the integration of foreign-trained immigrant professionals: Implications for smaller communities in Ontario. University of Guelph.

Goldberg, D.T., 1993. Racist Culture: Philosophy and the Politics of Meaning. 1st Edn., WileyBlackwell, Cambridge, ISBN: 0631180788, pp: 313.

Goldberg, M., 2000. The facts are in' Newcomers' experiences in accessing regulated professions in Ontario. Ontario Ministry of Training.

Graham, K.A., 1988. How Ottawa Spends: 1988-1989. 1st Edn., McGill-Queen's University Press, Ottawa, ISBN: 0886290716 , pp: 344.

Grant, M.L., 1999. Evidence of new immigrant assimilation in canada. Can. J. Econ. Rev. C Econ., 32: 930-955.

Gupta, T.D., 1996. Racism and Paid Work. 1st Edn., University of Toronto Press, Toronto, ISBN: 1442601183, pp: 118.

Halli, S.S., F. Trovato and L. Driedger, 1991. Ethnic Demography: Canadian Immigrant Racial and Cultural Variations. $1^{\text {st }}$ Edn., Carleton University Press, Ottawa, ISBN: 0886291089, pp; 497.

Harlos, K.P., M. Mallon, R. Stablein and C. Jones, 2003. Teaching qualitative methods in management classrooms. J. Manage. Educ., 27: 304-322. DOI: 10.1177/1052562903027003003

Henry, F. and E. Ginzberg, 1985. Who Gets the Work? A Test of Racial Discrimination in Employment. 1st Edn., Urban Alliance on Race Relations and Social Planning Council of Metropolitan Toronto, Toronto, ISBN: 1199021148 , pp: 87.

Henry, F., 2006. The Colour of Democracy: Racism in Canadian Society. 3rd Edn., Thomson Nelson, Toronto, ISBN: 0176224866, pp: 366,

Henry, F., Carol, Tator, Winston and Mattis et al., 1998. The Color of Democracy: Racism in Canadian Society. 1st Edn., Harcourt Brace and Company, Canada.

Hines, T., 2000. An evaluation of two qualitative methods (focus group interviews and cognitive maps) for conducting research into entrepreneurial decision making. Qual. Market Res. Int. J., 3: 716.DOI: $10.1108 / 13522750010310406$

Hum, D. and W. Simpson, 1999. Wage opportunities for visible minorities in Canada. Can. Pub. Policy, 25: 379-394.

Hum, D. and W. Simpson, 2002. Do immigrants catch up economically. Policy Opt. Montrea, 23: 47-50.

Khalema, N.E. and J. Wannas, 2003. Under the Prism of Suspicion: Minority Voices in Canada PostSeptember 11. J. Muslim Minority Affairs, 23: 2540. 
Kincheloe, J.L., 2010. Teaching Against Islamophobia. 1st Edn., Peter Lang, New York, ISBN: 1433103362, pp: 336.

Kluegel, J.R. and E.R. Smith, 1982. Whites' beliefs about blacks' opportunity. Am. Soc. Rev., 47: 518532.

Kluegel, J.R. and E.R. Smith, 1986. Belief About Inequality: American Views of What is and what Ought to be. 3rd Edn., Transaction Publishers, New York, ISBN: 0202303276, pp: 332.

Kluegel, J.R., 1990. Trends in whites' explanations of the black-white gap in socioeconomic status, 19771989. Am. Soc. Rev., 55: 512-525.

Krahn, H., T. Derwing, M. Mulder and L. Wilkinson, 2000. Educated and underemployed: Refugee integration into the Canadian labour market. J. Int. Migrat. Integrat., 1: 59-84. DOI: 10.1007/s12134000-1008-2

Li, P.S., 1988. Ethnic Inequality in a Class Society. 1st Edn., Thompson Educational Publishing, Toronto, ISBN: $1550770306, \mathrm{pp}: 180$.

Li, P.S., 2001. The market worth of immigrants' educational credentials. Can. Pub. Policy Anal. Pol., 27: 23-38.

Lopes, T. and B. Thomas, 2006. Dancing on Live Embers: Challenging Racism in Organizations. 1st Edn., Between the Lines, Toronto, ISBN: 1897071043, pp: 284.

MacBride-King, J.L. and P. Benimadhu, 2004. toward maximizing the Talents of Visible Minorities: Potential, Performance And Organizational Practices. 1st Edn., Conference Board of Canada, Ottawa, pp: 11.

Maxwell, J.A., 1992. Understanding and Validity in Qualitative Research. Harvard Educ. Rev., 62: 279-301.

Mensah, J., 2002. Black Canadians: History, Experience, Social Conditions. 2nd Edn., Fernwood Publishing Co., Ltd., ISBN: 1552663450 , pp: 3495.

Miles, M. B. and A.M. Huberman, 1994. Qualitative Data Analysis: An Expanded Sourcebook. 2nd Edn., Sage Publications, Thousand Oaks, ISBN: 0803946538, pp: 338.

Myers, K., 2005. Racetalk: Racism Hiding in Plain Sight. 1st Edn., Rowman and Littlefield, Lanham, ISBN: 0742535347, pp: 299.

NSO, 1995. Census of population. 1st Edn., National Statistics Office, Manila.

O’Connor, C., 1999. Race, class and gender in america: Narratives of opportunity among low-income african american youths. Soc. Educ., 72: 137-157.
Ontario Human Rights Commission, 1983. Experience of Visible Minorities in the Work World: The Case of MBA Graduates. 1st Edn., The Commission, Toronto, pp: 175.

Pendakur, K. and R. Pendakur, 1998. The colour of money: Earnings differentials among ethnic groups in Canada. Can. J. Econ. Rev. Can. Econ., 31: 518548.

Percy-Smith, J., 2000. Policy Responses to Social Exclusion: Towards Inclusion. 1st Edn., Open University Press, Buckingham, ISBN: 0335204732, pp: 244.

Reitz, J.G., 2001. Immigrant skill utilization in the Canadian labour market: Implications of human capital research. J. Int. Migrat. Integrat., 2: 347378. DOI: $10.1007 / \mathrm{s} 12134-001-1004-1$

Samuel, T.J. and A. Karim, 1996. Employment equity and visible minorities in federal workforce. Proceedings of the Paper Presented at the Symposium on Immigration and Integration, (PPSII'96), CERIS, Montreal, Canada.

Samuel, T.J. and A. Karam, 2000. Employment Equity for Visible Minorities. In: Race and Racism: Canada's Challenge, Driedger, L. and S.S. Halli, (Eds.). McGill-Queen's Press, ISBN: 0886293650, Montreal, pp: 134-149.

Sawan, N., 1991. Economic and Social Impacts of Immigration. 1st Edn., The Council, Ottawa, ISBN: 0660139553, pp: 166.

SC, 2003. Longitudinal survey of immigrants to canada: Process, Progress and Prospects. Statistics Canada, Ottawa, pp: 46.

Schultz, T.W., 1961. Investment in human capital. Am. Econ. Rev., 51: 1-17.

Skinner, D., C. Tagg and J. Holloway, 2000. Managers and research: The pros and cons of qualitative approaches. Manage. Learn., 31: 163-180.

Stasiulis, D.K., 1990. Multiculturalism and the economic agenda in Australia: Adult E.S.L., Overseas Skills Recognition and Anti-Racist Strategies. 1st Edn., Policy and Research, Multiculturalism Sector, Ottawa, pp: 112.

Strauss, A. L. and J. Corbin, 1990. Basics of qualitative research: Basics of qualitative research: Grounded Theory Procedures and Techniques. 17th Edn., Sage, Newbury Park, Calif., ISBN: 0803932502, pp: 270 .

TBCS, 2000. Embracing change in the federal public service-task force on the participation of visible minorities in the federal public service. 1st Edn., Treasury Board of Canada Secretariat. 
Teelucksingh, C. and G.E. Galabuzi, 2005. Impact of race and immigrants status on employment opportunities and outcomes in the canadian labour market. CERIS.

Torczyner, J.L. and Sharon, 2001. The Evolution of the Black Community of Montreal: Change and Challenge October 2001. 1st Edn., McGill School of Social Work, Montreal, ISBN: 1896456456, pp: 113.

Ulmer, J.T. and M.S. Wilson, 2003. The Potential Contributions of Quantitative Research to Symbolic Interactionism. Symbol. Int., 26: 531552.

Walker, J.W.S.G. 1980. A History of Blacks in Canada. 1st Edn., Minister of State and Multiculturalism, Ottawa, ISBN: 066010735X, pp: 181.
Watt, D. and M. Blooom, 2001. Exploring the Learning Recognition Gap in Canada. Recognizing Learning: the Economic Costs of not Recognizing Learning and Learning Credentials in Canada. 1st Edn., Conference Board of Canada, Toronto,pp: 49.

Wherrett, J., 1997. The Indian Act: Proposed Modifications. 1st Edn., Library of Parliament, Research Branch, Ottawa, ISBN: 0660170582, pp: 14. 